\title{
The Effects of Ligation of Vas Deferens, Corpus Epididymidis and Vasa Efferentia on the Testicular Function in Rats
}

\author{
Masaaki Kuwahara \\ Department of Urology, Akita University School of Medicine, \\ Akita
}

\begin{abstract}
KuWahara, M. The Effects of Ligation of Vas Deferens, Corpus Epididymidis and Vasa Efferentia on the Testicular Function in Rats. Tohoku J. exp. Med., 1976, 120 (3), 251-257 — The effects of ligation of the vas deferens, the corpus epididymidis and the vasa efferentia on the testicular function were studied in sexually mature rats. The significant decrease in the testicular weight was observed after ligation of the corpus epididymidis and the vasa efferentia. However, neither the weight of the ventral prostate and of the seminal vesicle, nor the plasma testosterone level showed significant changes. The results suggest that the ligation at the three locations would not affect the endocrine function of the testis. The changes in the testis would mainly affect the spermatogenesis. The effects of sperm stasis on the testicular function were also discussed. vas deferens; corpus epididymidis; vasa efferentia; testicular function
\end{abstract}

Vasectomy has been generally accepted as a safe procedure in male contraceptions and used widely in the world as a means of population control. In recent years several reports have directed an attention to the relationship between an accumulation of the sperm in the ductal system and testicular function (Horan 1973, 1975; Johnson and Howards 1975; Kuwahara and Frick 1975). Horan (1975) has shown in his animal experiments that epididymal stasis of the sperm caused testicular atrophy, and when the stasis was dominant, testicular effects were invariably seen. He has further noticed interstitial cell hyperplasia after vasectomy which was reported also in man (Gupta et al. 1975). Kuwahara and Frick (1975) have shown a discrepancy of testicular histology between rats which formed the spermatic cyst after the ligations and those which did not. These observations suggest that the sperm stasis would affect the testicular function.

Vasectomy or vasoligation is not necessarily an adequate procedure for the investigation of sperm stasis, because postoperative formation of the spermatic cyst and absorptive function of the epididymis would influence the results. The purpose of this investigation is to study the effect of sperm stasis on the testicular function by means of the ligation at three different locations of the ductal system; namely, vas deferens, corpus epididymidis and vasa efferentia.

Received for publication, June 1, 1976. 


\section{Materials and Methods}

Animals. A total of 44 mature Wistar rats, weighing $230-270 \mathrm{~g}$, were used. They were divided into the following four groups: Group A, 14 rats for control sham-operation; Group B, 10 rats for vasoligation; Group C, 10 rats for ligation of corpus epididymidis: and Group D, 10 rats for ligation of vasa efferentia. The ligation procedure at different locations of the ductal system was the same as in the previous paper (Kuwahara and Frick 1975), except that the operation was performed bilaterally. The animals were maintained on a cycle of twelve hr light and twelve hr dark after the operation. Forty days after the surgery each rat was weighed and then killed by a blow on the head. The testis, epididymis, seminal vesicle and ventral prostate were removed and weighed. The blood was taken at the same time from the vena cava for evaluation of testosterone. The radioimmunoassay was used to determine testosterone in the plasma as described by Furuyama et al. (1970).

\section{Regults}

The results of experiments in each group are shown in Tables 1 to 4 . Analysis of variance by $t$-test is shown in Table 5 .

\section{Body weight}

The mean body weight in the groups $B$ and $C$ was lower than in the control group $(p<0.05)$.

\section{Testicle weight}

The testicle weight in the groups $C$ and $D$ was lower than that in the control group $(p<0.01)$.

\section{Epididymis weight}

A marked increase in weight was observed in the epididymis head of the group

TABLE 1. Control sham operation (Group A)

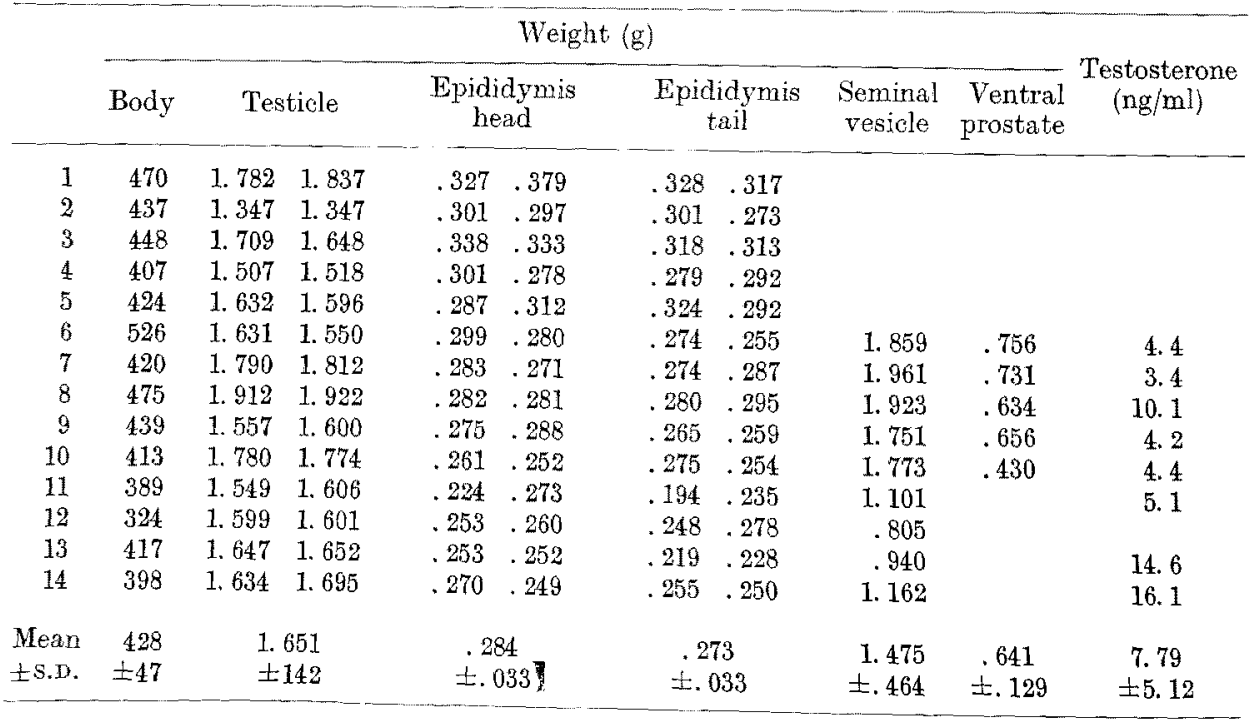


TABLE 2. Vasoligation (Group B)

\begin{tabular}{|c|c|c|c|c|c|c|c|c|c|}
\hline \multirow[b]{3}{*}{1} & \multicolumn{8}{|c|}{ Weight (g) } & \multirow{2}{*}{$\begin{array}{l}\text { Testosterone } \\
\quad(\mathrm{ng} / \mathrm{ml})\end{array}$} \\
\hline & \multirow{2}{*}{$\begin{array}{r}\text { Body } \\
353\end{array}$} & \multicolumn{2}{|c|}{ Testicle } & \multicolumn{2}{|c|}{$\begin{array}{l}\text { Epididymis } \\
\text { head }\end{array}$} & $\begin{array}{c}\text { Epididymis } \\
\text { tail }\end{array}$ & \multirow{2}{*}{$\begin{array}{c}\begin{array}{c}\text { Seminal } \\
\text { vesicle }\end{array} \\
1.577\end{array}$} & \multirow[t]{2}{*}{$\begin{array}{l}\text { Ventral } \\
\text { prostate }\end{array}$} & \\
\hline & & 1. 540 & 1. 580 & .255 & . 244 & $.480^{*} .481^{*}$ & & & \\
\hline 2 & 366 & 1. 664 & 1. 744 & .312 & 324 & $461^{*} .481^{* \dagger}$ & 1. 293 & & \\
\hline 3 & 357 & 1.452 & 1.465 & .257 & 263 & $430^{*} \dagger .625^{*}$ & 1.478 & & \\
\hline 4 & 320 & 1. 311 & 1. 442 & .216 & 238 & $646^{*}+.491^{*} \dagger$ & 1. 873 & & \\
\hline 5 & 361 & 1.555 & 1. 622 & .239 & 260 & $882^{*} .475$ & 1.723 & & \\
\hline 6 & 458 & 1. 710 & 1. 750 & .299 & 316 & $241^{*} .250^{*}$ & 1. 876 & 675 & 10.8 \\
\hline 7 & 396 & 1. 654 & 1. 754 & .276 & 288 & $668^{*} .253 \dagger$ & 1.586 & .659 & 8.9 \\
\hline 8 & 439 & 1. 679 & 1. 773 & .304 & 320 & $.300 \dagger$ & 1. 853 & .907 & 6.9 \\
\hline 9 & 395 & 1. 781 & 1. 792 & .226 & 227 & $.602^{*} .266 \dagger$ & 1. 881 & 690 & 10.7 \\
\hline 10 & 326 & 1. 522 & 1. 564 & .265 & 241 & $.233 \dagger .263 \dagger$ & 1. 809 & 691 & 8.2 \\
\hline $\begin{array}{l}\text { Mean } \\
\pm \text { S.D. }\end{array}$ & $\begin{array}{r}377 \\
\pm 45\end{array}$ & & $\begin{array}{l}651 \\
135\end{array}$ & $\begin{array}{r}2 \\
\pm .8\end{array}$ & & $\begin{array}{l}.441 \\
\pm .180\end{array}$ & $\begin{array}{r}1.695 \\
\pm .204\end{array}$ & $\begin{array}{c}.724 \\
+\quad 103\end{array}$ & $\begin{array}{l}9.1 \\
+1.7\end{array}$ \\
\hline
\end{tabular}

* Spermatic cyst formed. $\dagger$ Spermatic cyst formed at the vas deferens.

TABLe 3. Corpus epididymidis ligation (Group C)

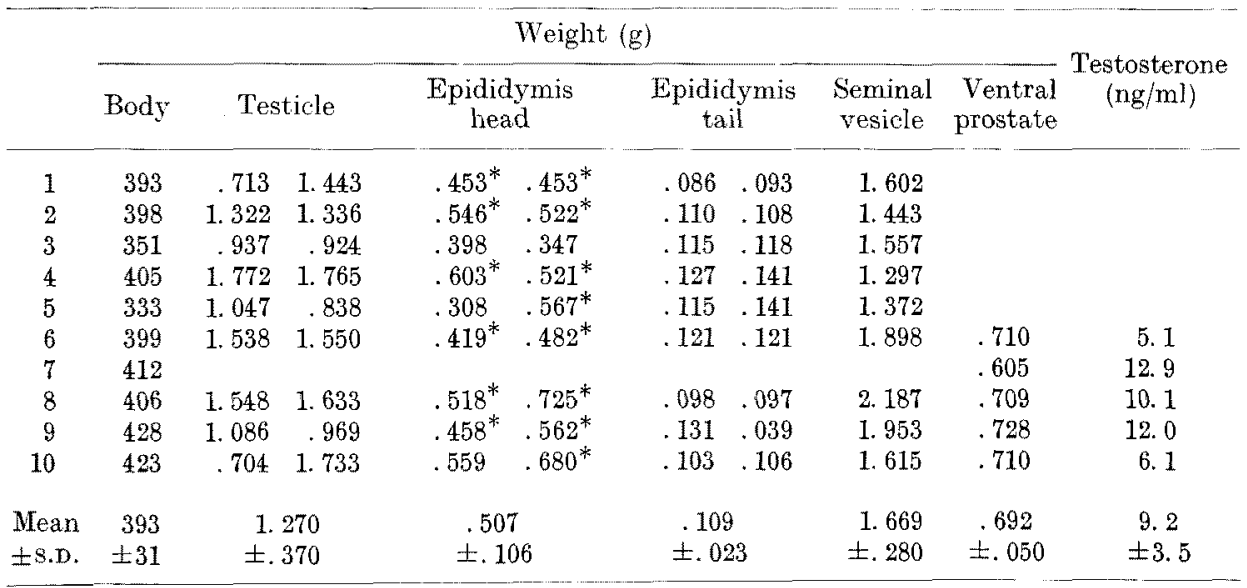

* Spermatic cyst formed.

$C$ and in the tail of the group B. The lower weight was observed in the epididymis head of the group D, and in the epididymis tail of the groups C and D. These differences were stochastically significant $(p<0.01)$.

Weight of seminal vesicle and ventral prostate

The seminal vesicle and ventral prostate tended to increase in weight in each ligated group, although not significant stochastically.

\section{Plasma testosterone}

A marked individual variation was observed in each group. Analysis of variance indicated no significant difference. 
TABLE 4. Vasa efferential ligation (Group D)

\begin{tabular}{|c|c|c|c|c|c|c|c|c|c|c|}
\hline & \multicolumn{9}{|c|}{ Weight (g) } & \multirow{2}{*}{$\begin{array}{l}\text { Testosterone } \\
\quad(\mathrm{ng} / \mathrm{ml})\end{array}$} \\
\hline & \multirow{2}{*}{$\begin{array}{r}\text { Body } \\
446\end{array}$} & \multicolumn{2}{|c|}{ Testicle } & \multicolumn{2}{|c|}{$\begin{array}{l}\text { Epididymis } \\
\text { head }\end{array}$} & \multicolumn{2}{|c|}{$\begin{array}{l}\text { Epididymis } \\
\text { tail }\end{array}$} & \multirow{2}{*}{$\frac{\begin{array}{c}\text { Seminal } \\
\text { vesicle }\end{array}}{1.681}$} & \multirow[t]{2}{*}{$\begin{array}{l}\text { Ventral } \\
\text { prostate }\end{array}$} & \\
\hline 1. & & 1. 585 & 1. 570 & .299 & .240 & .272 & .262 & & & \\
\hline 2. & 382 & 1. 450 & 1. 099 & .240 & .135 & .218 & .113 & 1.151 & & \\
\hline 3. & 434 & 1. 718 & 1. 586 & .287 & 219 & .274 & .199 & 1. 060 & & \\
\hline 4. & 379 & 1. 818 & 1. 608 & .295 & 157 & .272 & .128 & 1. 212 & & \\
\hline 5. & 429 & 1. 054 & 1.612 & .146 & 278 & .129 & .285 & 2. 042 & & \\
\hline 6. & 423 & .919 & .957 & .176 & 207 & .172 & 172 & 2. 624 & .772 & 12.4 \\
\hline 7. & 486 & 1. 636 & 1. 383 & .142 & 150 & .132 & .150 & 1. 674 & .934 & 1.0 \\
\hline 8. & 471 & 1. 140 & 1. 201 & .175 & .155 & .140 & .117 & 1. 843 & 1. 004 & 2.1 \\
\hline 9. & 440 & 1. 624 & 1.655 & .189 & 172 & .155 & .132 & 1.724 & .614 & 3.3 \\
\hline 10. & 474 & 1. 625 & 1. 383 & .142 & .187 & .150 & .142 & 1.648 & .570 & 5.3 \\
\hline $\begin{array}{l}\text { Mean } \\
\pm \text { S.D. }\end{array}$ & $\begin{array}{r}436 \\
\pm 36\end{array}$ & & $\begin{array}{l}431 \\
272\end{array}$ & $\begin{array}{r}.20 \\
\pm .0\end{array}$ & & $\begin{array}{r}.18 \\
\pm .0\end{array}$ & & $\begin{array}{r}1.666 \\
\pm .463\end{array}$ & $\begin{array}{l}779 \\
\pm .190\end{array}$ & $\begin{array}{c}4.8 \\
\pm 4.5\end{array}$ \\
\hline
\end{tabular}

Spermatic cyst

Spermatic cysts were formed in the groups B and C, but not in the group D. The location was mainly the ligated site proximal to the testis. In the group $B$, the cysts were found in 19 out of 20 (95\%) as shown in Table 2 , and 23 cysts in total were present; 10 at the vas deferens and 13 at the epididymis tail. In the group $\mathrm{C}$, the cysts were found in 14 out of $20(70 \%)$ as shown in Table 3 , and all cysts were observed at the ligated site near the epididymis.

\section{Discussion}

Our results indicate that a significant decrease in testicle weight develops after ligation of the corpus epididymidis or of the vasa efferentia, but not of the vas deferens. Although the decrease in the testicular weight might possibly be associated with some changes of endocrine function of the testis, there was no evidence of such change from the weight of accessory organs, a seminal vesicle and a ventral prostate. Plasma testosterone also showed no significant change in the

TABLE 5. Summarized results and

\begin{tabular}{cccc}
\hline & \multicolumn{3}{c}{ Weight $(\mathrm{g})$ Mean \pm s.D. } \\
\cline { 2 - 4 } & Body & Testicle & Epididymis head \\
A. control & $428 \pm 47$ & $1.651 \pm 0.142$ & $0.284 \pm 0.033$ \\
& $n=14$ & $n=28$ & $n=28$ \\
B. vas df. & $377 \pm 45^{*}$ & $1.618 \pm 0.135$ & $0.269 \pm 0.034$ \\
& $n=10$ & $n=20$ & $n=20$ \\
C. corp. ep. & $393 \pm 31^{*}$ & $1.270 \pm 0.370 \dagger$ & $0.507 \pm 0.106 \dagger$ \\
D. vasa ef. & $n=10$ & $n=18$ & $n=18$ \\
& $436 \pm 36$ & $1.431 \pm 0.272 \dagger$ & $0.200 \pm 0.056 \dagger$ \\
& $n=10$ & $n=20$ & $n=20$ \\
\hline
\end{tabular}

Differences from control $* p<0.05,+p<0.01, n=$ number of samples. 
ligted groups compared with the control group.

The cause of a decrease in testicular weight is unknown. However, a hydrostatic effect due to the ligation is suggested. Horan (1975) showed in human studies that when the stasis of sperm in the epididymis was high, it had invariably some effects on the testis. He also noted in another paper (1973) that vasoligation animals, in which complete and long-term stasis was achieved, had either substantial impairment of spermatogenesis or testicular atrophy. The present results that the group of vasoligation showed no significant decrease in the testicular weight were in accord with many previous papers (Kar et al. 1965; McGlynn and Erpino 1974; Neaves 1974, 1975; Howards et al. 1975). The difference in the results from the ligation of the corpus epididymidis or the vasa efferentia, in which a decrease in the testicular weight was observed, is probably due to whether or not the whole epididymis is preserved with the testis. In the ligation of the vasa efferentia in which the testis is isolated from the epididymis, the degeneration was observed in seminiferous tubules in animal experiments (Smith 1961-1962; Kuwahara and Frick 1975). Horan (1975) reported also in his human studies that the testes from the patients whose vasa efferentia had been ligated previously showed "ghosts" of seminiferous tubules. These findings suggest a great role of the epididymis in maintaining the testis after the ligation.

It is well known that the epididymis and vasa efferentia have an absorptive function. Reid and Cleland (1957) showed that the concentration of spermatozoa was lower in the rete testes but rose rapidly in the terminal part of the vasa efferentia and reached the maximum in the zone 2 of the epididymis. Levine and Marsh (1971) showed that the epididymis reabsorbed about $70 \%$ of the fluid formed in the seminiferous tubules. The more proximal region reabsorbs about $46 \%$ of the fluid, and the remainder of the epididymis $23 \%$. In addition, spermatic cysts at the cut end of the vas deferens or the epididymis are observed both in vasectomized man (Schmidt 1966) and in animals (Smith 1961-1962; Flickinger 1972; Sackler et al. 1973; Kwart and Coffey 1973; Neaves 1974; Howards et al. 1975). The significant weight changes of the head and tail of the epididymis seem to be simply explained by whether an inflow of spermatic fluid is blocked and whether a

analysis of variance by t-test

\begin{tabular}{cccc}
\hline Epididymis tail & Seminal vesicle & Ventral prostate & Testosterone (ng/ml) \\
\hline $0.273 \pm 0.033$ & $1.475 \pm 0.464$ & $0.641 \pm 0.129$ & $7.79 \pm 5.12$ \\
$n=28$ & $n=9$ & $n=5$ & $n=8$ \\
$0.441 \pm 0.180 \dagger$ & $1.695 \pm 0.204$ & $0.724 \pm 0.103$ & $9.1 \pm 1.7$ \\
$n=20$ & $n=10$ & $n=5$ & $n=5$ \\
$0.109 \pm 0.023 \dagger$ & $1.669 \pm 0.280$ & $0.692 \pm 0.050$ & $9.2 \pm 3.5$ \\
$n=18$ & $n=9$ & $n=5$ & $n=5$ \\
$0.181 \pm 0.060 \dagger$ & $1.666 \pm 0.463$ & $0.779 \pm 0.190$ & $4.8 \pm 4.5$ \\
$n=20$ & $n=10$ & $n=5$ & $n=5$ \\
\hline
\end{tabular}


spermatic cyst is formed. McGlynn and Erpino (1974) showed the significant weight changes after vasectomy on similar occasion. After the ligation a spermatic cyst would act as a kind of "shock absorber" in the ductal system and protect the testis from the abnormal pressure for a relatively long period. It seems therefore likely that when hydrostatic changes occur in the ductal system by the ligation, both the absorptive function and the volume of the organs, including a spermatic cyst, contribute to controlling intracanalicular pressure and prevent the testes from its deleterious effect. If the spermatic cysts were to continue to extend into the efferent ducts, they cause also suppression of the testicular function (Kwart and Coffey 1973). These absorptive function would be more active after the ligation than in the normal condition.

Recently, Johnson and Howards (1975) measured intratubular hydrostatic pressure in seminiferous tubules after vasectomy and concluded that a decline in spermatogenesis and/or fluid secretion was not the direct results of increased pressure in the seminiferous tubules or caput epididynidis. In spite of their findings, the possibility of the hydrostatic effect on the testis cannot be excluded, because they observed a significant decrease in testicular weight at the same time. In this regard a question still remains whether or not their findings reflected the condition in which the effect of the ligation, i.e., the hydrostatic effect, already had developed in the testis. Their findings would agree with those of the ligation of the corpus epididymidis and vasa efferentia in our case. The difference in the testicular weight would probably be attributed to the differences of experimental animals and of the observation day after the surgery. They used hamsters and observed the result in two weeks after vasectomy.

There are several reports of interstitial cell hyperplasia after vasectomy in man (Horan 1975; Gupta et al. 1975) and in animal (Kothari et al. 1973). Gupta et al. (1975) discussed in the light of Steinach's original hypothesis (1927) that vasectomy could rejuvenate aging males by improving the endocrine function of the testes. However, it is obvious that interstitial cell hyperplasia under a microscope is only an indirect index of the testicular endocrine function. It is generally accepted that vasectomy induces no significant change in hormonal condition according to testosterone, FSH and LH measurements (Johnsonbaugh et al. 1975; Varma et al. 1975).

As to the testosterone determination in rats, the findings of Bartke et al. (1973) are noteworthy. They showed that there was a striking individual variation in the values of rats and mice. They pointed out further that two- to three-fold fluctuations in testosterone concentration in plasma were detected even in the same animal at different times. Therefore, the weight of the accessory organs would be more reliable than the testosterone level in detecting a change of testicular endocrine function in rats.

\section{Acknowledgment}

This study was supported by a grant from the Population Council. I would like to thank Dr. W.R. Fair, Stanford University, for his advice and help to the experiments. I would also thank Dr. K. Sundaram, the Population Council, for the antitestosterone-3-BSA. 


\section{References}

1) Bartke, A., Steele, R.E., Musto, N. \& Caldwell, B.V. (1973) Fluctuations in plasma testosterone levels in adult male rats and mice. Eindocrinology, 92, 1223-1228.

2) Flickinger, C.J. (1972) Ultrastructure of the rat testis after vasectomy. Anat. Rec., 174, 477-494.

3) Furuyama, S., Darrel, M.M. \& Charles, A.N. (1970) A radioimmunoassay for plasma testosterone. Steroids, 16, 415-428.

4) Gupta, A.S., Kothari, L.K., Dhruva, A. \& Bapna, R. (1975) Surgical sterilization by vasectomy and its effect on the structure and function of the testis in man. Brit. J. Surg., 62, 59-63.

5) Horan, A.H. (1973) The pathogenesis of hydro-testis after ligation of the vas deferens: A study in several species. J. Urol., 110, 317-321.

6) Horan, A.H. (1975) When and why does occlusion of the vas deferens affect the testes? Fertil. and Steril., 26, 317-328.

7) Howards, S., Jessee, S. \& Johnson, A. (1975) Micropuncture and microanalytic studies of the effect of vasectomy on the rat testis and epididymis. Fertil. and Steril., 26, 20-28.

8) Johnson, A.L. \& Howards, S.S. (1975) Intratubular hydrostatic pressure in testis and epididymis before and after vasectomy. Amer. J. Physiol., 228, 556-564.

9) Johnsonbaugh, R.E., O'Connell, K., Engel, S.B., Edson, M. \& Sode, J. (1975) Plasma testosterone, luteinizing hormone and follicle-stimulating hormone after vasectomy. Fertil and Steril., 26, 329-330.

10) Kar, A.B., Chandra, H. \& Kamboj, V.P. (1965) Long-term effect of vasectomy on the gonad-pituitary system of rats. Acta biol. med. germ., 15, 381-385.

11) Kothari, L.K., Mishra, P. \& Mishra, E.K. (1973) Effect of bilateral vasectomy on the structure and function of the testes. Amer. J. Surg., 126, 84-88.

12) Kuwahara, M. \& Frick, J. (1975) The ligation of the male reproductive organs and the role of the spermatic cyst. Andrologia, 7, 1-14.

13) Kwart, A. \& Coffey, D.S. (1973) Sperm granulomas: an adverse effect of vasectomy. J. Urol., $110,416-422$.

14) Levine, N. \& Marsh, D.J. (1971) Micropuncture studies of the electrochemical aspects of fluid and electrolite transport in individual seminiferous tubules, the epididymis and the vas deferens in rats. $J$. Physiol., 213, 557-570.

15) McGlynn, J.M. \& Erpino, M.J. (1974) Effects of vasectomy on the reproductive system and sexual behavior of rats. J. Reprod. Fertil., 40, 241-247.

16) Neaves, W.B. (1974) The rat testis after vasectomy. J. Reprod. Fertil., 40, $39-44$.

17) Neaves, W.B. (1975) The androgen status of vasectomized rats. Endocrinology, 96, 529-534.

18) Reid, B. \& Cleland, K.W. (1957) The structure and function of the epididymis. I: The histology of the rat epididymis. Aust. J. Zool., 5, 223-246.

19) Sackler, A.M., Weltman, A.S., Pandhi, V. \& Schwartz, R. (1973) Gonadal effects of vasectomy and vasoligation. Science, 179, 293-295.

20) Schmidt, S.S. (1966) Technics and complications of elective vasectomy. The role of spermatic granuloma in spontaneous recanalization. Fertil. and Steril., 17, 467-479.

21) Smith, G. (1961-1962) The effects of ligation of the vasa efferentia and vasectomy on testicular function in the adult rat. $J$. Endocr., 23, 385-399.

22) Steinach, E. (1927) Biological methods against the process of old age. Med. $J$. Rec., 125, 77-81.

23) Varma, M.M., Varma, R.P., Johanson, A.J., Kowarski, A. \& Migeon, C.J. (1975) Long-term effects of vasectomy on pituitary-gonadal function in man. $J . \mathrm{clin}$. Endocr., 40, 868-871. 